\title{
PERSEPSI MAHASISWA TERHADAP MATA KULIAH SISTEM INFORMASI : STUDI KASUS MAHASISWA JURUSAN AKUNTANSI UNIVERSITAS ANDALAS
}

\author{
Verni Juita \\ Jurusan Akuntansi, Fakultas Ekonomi Universitas Andalas
}

\begin{abstract}
The growing needs for accountants, especially for those who can use and understand information technology, has encouraged accounting programs at the higher education level to offer information system courses. Given this fact, this study aims to (1) assess the students' perception on the importance and relevance of the information system courses for their major and future works, (2) examine the relationship between the student's awareness on information system subjects and their performance in these subjects, (3) identify the factors influencing the students' perception on teaching practices in information system courses. The data was collected through questionnaires which were distributed to accounting students in the Faculty of Economics, Andalas University. This research found that a better understanding on teaching materials of the information system courses have helped students to understand other subjects taught in the accountancy program. Moreover, the student's motivation, views and the lecturer's teaching methods and knowledge are the main contributors for the student's success in these courses.
\end{abstract}

Keywords: student's perception, accounting information system

1. Pendahuluan
1.1. Latar belakang
Revolusi sistem informasi yang
disebabkan oleh perkembangan
tekhnologi yang begitu pesat
mempengaruhi segala bidang di dalam
dunia bisnis. Hampir semua
perusahaan maupun organisasi baik
yang besar maupun yang kecil sudah
mengimplementasikan tekhnologi
informasi dalam menjalankan
kegiatannya (Laudon dan
Laudon,2000). Hal ini dikarenakan
dalam dunia bisnis saat ini sistem
informasi, internet dan jaringan global
lainnya memberi banyak keuntungan.
Selain memudahkan pelaksanaan
aktivitas juga dapat membangun
keunggulan kompetitif bagi organisasi
yang mengaplikasikannya.
$\begin{aligned} & \text { Perusahaan atau organisasi bisa } \\ & \text { menciptakan inovasi dan melebarkan }\end{aligned}$
lingkup bisnisnya ke daerah lain yang
secara lokasi letaknya sangat jauh.
Kendala serta permasalahan
komunikasi, pengawasan, maupun
koordinasi manajemen yang
disebabkan oleh keterbatasan

geografis dan hal lainnya bisa diatasi dengan pengaplikasian tekhnologi. Dibandingkan dengan proses bisnis yang konvensional, proses bisnis elektronik juga menginspirasi perusahaan dan organisasi untuk melaksanakan kegiatan operasional yang efektif dan efisien serta meningkatkan komunikasi dengan semua pihak baik di dalam maupun diluar organisasi seperti konsumen atau pemasok (Singleton, 2004). Perubahan dalam cara kerja ini memunculkan kebutuhan akan tenaga kerja yang bisa menyesuaikan diri dengan kondisi saat ini dan faham tekhnologi. Tidak hanya tenaga kerja yang ditugaskan khusus menjalankan atau mengurus sistem informasi yang ada, tapi juga semua tenaga kerja di berbagai bidang yang bisa bertindak sebagai pemakai sistem itu sendiri.

Kesempatan karier untuk lulusan bidang Akuntansi sendiri terbuka lebar, tidak hanya terfokus sebagai Akuntan Keuangan, Akuntan Manajemen, maupun auditor tapi juga dalam bidang lainnya khususnya yang berhubungan 
dengan Sistem Informasi. Selain berkarir di bidang keuangan yang juga bersentuhan dengan tekhnologi dan sistem informasi, Akuntan juga bisa berperan lebih aktif dalam Sistem Informasi dengan posisi sebagai analyst maupun anggota tim pengembangan system. Menurut Hall dan Singleton (2005) peran Akuntan dalam pengembangan system terdiri atas 3 (tiga) yaitu:

a) Akuntan sebagai Users (pengguna Sistem)

b) Akuntan sebagai anggota team pengembangan sistem

c) Akuntan sebagai Auditor.

Kebutuhan akan tenaga kerja yang sadar, faham, mampu menggunakan tehnologi dengan dan memahami Sistem Informasi memunculkan peluang bagi institusi pendidikan yang merupakan penyedia lulusan yang kompeten dan siap pakai dalam dunia kerja. Hampir semua bidang ilmu melakukan penyesuaian dengan memasukkan aplikasi tekhnologi dan sistem informasi sebagai salah satu pengetahuan yang harus dimiliki oleh mahasiswanya disamping pengetahuan utama. Universitas Andalas terutama Jurusan akuntansi sebagai salah satu Institusi penyedia tenaga kerja siap pakai pun menyadari pentingnya melakukan penyesuaian kurikulum dan mata kuliah yang ditawarkan.

Diawali dengan menawarkan dua mata kuliah berkaitan dengan sistem Informasi yaitu Sistem Informasi Akuntansi (SIA), dan Sistem Informasi Manajemen (SIM). Berikutnya jurusan Akuntansi menambah mata kuliah Analisa Perancangan Sistem (APS) dan Audit Sistem Informasi untuk semakin mempertajam daya saing lulusan. Semua mata kuliah tersebut penting untuk dikuasai dan dipahami oleh semua mahasiswa Akuntansi. IImu yang didapat dalam mata kuliah tersebut juga membutuhkan pemahaman mereka tentang bidang ilmu utama (yaitu Akuntansi) yang sudah mereka pelajari. Salah satu contoh adalah mata kuliah Sistem Informasi Akuntansi membutuhkan pemahaman mahasiswa tentang alur transaksi akuntansi pada setiap proses agar dapat menghasilkan informasi akuntansi yang akurat dan jelas sebagai output.

Sebagaimana mata kuliah lain, efektifitas pencapaian tujuan ditawarkannya mata kuliah yang berkaitan dengan sistem informasi di atas dipengaruhi oleh banyak hal seperti : ketersediaan fasilitas, faktorfaktor yang datang dari diri pengajar, maupun factor-faktor yang berasal dari diri mahasiswa itu sendiri. Dari ketiga hal yang mempengaruhi efektivitas pencapaian tujuan perkuliahan, penulis tertarik untuk meneliti faktor yang datang dari diri mahasiswa itu sendiri. Faktor yang datang dari diri mahasiswa bisa bermacam-macam seperti kedisiplinan, kesadaran, persepsi, dan lain lain. Salah satu hal yang penting adalah bagaimana persepsi mahasiswa terhadap mata kuliah mata kuliah sistem informasi yang dapat mempengaruhi keberhasilannya dalam memahami / mempelajari mata kuliah tersebut.

Persepsi itu sendiri diartikan sebagai proses akhir dari aktifitas observasi yang dimulai dengan proses penginderaan, yaitu proses diterimanya stimulus oleh indera, kemudian stimulus menimbulkan perhatian yang diteruskan ke otak dan dilanjutkan dengan kesadaran individu. Kesadaran inilah yang dinamakan persepsi (Sunaryo, 2004 dalam Adriansyah, 2011). Dengan persepsi, individu dibantu untuk menyadari dan mengerti tidak hanya tentang hal-hal yang berada di sekitarnya akan tetapi juga tentang hal yang terdapat di dalam diri individu yang bersangkutan.

Persepsi sebagai faktor yang muncul dalam diri mahasiswa itu sendiri diyakini sebagai salah satu faktor utama yang memotivasi dan mempengaruhi keberhasilan dalam belajar. Akan tetapi bagaimana fenomena persepsi para mahasiswa Akuntansi di Universitas Andalas dan seberapa besar persepsi ini mempengaruhi keberhasilan mereka dalam mempelajari mata kuliah Sistem Informasi masih dalam tanda tanya. Sementara informasi mengenai seberapa besar mahasiswa menganggap mata kuliah ini relevan dengan ilmu Akuntansi sangat 
berguna. Hal ini bisa digunakan untuk perbaikan metode ajar, peningkatan motivasi dan kesadaran mahasiswa dalam mempelajari mata kuliah Sistem Informasi yang saat ini sudah menjadi keharusan.

\subsection{Perumusan Masalah}

Menyadari urgensi pentingnya ilmu dalam semua mata kuliah sistem informasi yang ditawarkan oleh jurusan Akuntansi Universitas Andalas dalam menyiapkan lulusannya, dan mengingat persepsi mahasiswa bisa menjadi salah satu hal penting yang dapat memperbaiki pemahaman dan peningkatan motivasi mereka dalam semua matakuliah sistem informasi yang mereka pelajari. Maka penelitian ini akan membahas mengenai persepsi mahasiswa Akuntansi di Universitas Andalas terhadap mata kuliah Sistem Informasi. Secara spesifik, permasalahan yang akan dijawab melalui penelitian ini adalah:

1. Bagaimana persepsi / pandangan mahasiswa Akuntansi terhadap mata kuliah sistem informasi dibandingkan dengan mata kuliah lainnya?

2. Bagaimana persepsi/pandangan mahasiswa jurusan Akuntansi terhadap relevansi bidang ilmu Sistem Informasi dengan Akuntansi?

3. Seberapa besar persepsi mahasiswa tersebut mempengaruhi tingkat keberhasilannya dalam mempelajari mata kuliah tersebut?

4. Faktor-faktor apa saja yang dapat mempengaruhi terbentuknya persepsi mahasiswa Akuntansi terhadap mata kuliah sistem informasi?

\subsection{Tujuan Penelitian}

Penelitian ini bertujuan untuk:

1. Memperoleh gambaran umum mengenai pengajaran mata kuliah Sistem Informasi yang meliputi mata kuliah Sistem Informasi Akuntansi, Sistem Informasi Manajemen, Analisa Perancangan Sistem, dan Audit Sistem Informasi di jurusan Akuntansi Universitas Andalas.

2. Mengetahui persepsi para mahasiswa terhadap mata kuliah sistem informasi yang meliputi pengajaran, materi kuliah, relevansi dengan bidang ilmu Akuntansi dan keterpakaiannya di masa datang dalam dunia kerja.

3. Mengetahui seberapa besar persepsi para mahasiswa mempengaruhi tingkat keberhasilan mereka dalam mempelajari mata kuliah tersebut.

4. Mengidentifikasi berbagai faktor yang mempengaruhi persepsi mahasiswa jurusan Akuntansi.

5. Memperkaya literatur terkait dengan mata kuliah sistem informasi pada jurusan akuntansi

\subsection{Manfaat penelitian}

Adapun sasaran akhir dari penelitian ini adalah hasil dari penelitian ini diharapkan dapat memberikan kontribusi bagi banyak pihak diantaranya:

1. Masukan bagi para pengajar mata kuliah sistem informasi untuk mendapatkan gambaran bagaimana pengajaran mata kuliah Sistem Informasi dari sudut pandang mahasiswa. Selanjutnya memotivasi para pengajar mereview kembali metode pengajaran dan mempertimbangkan mengaplikasikan faktor yang dapat mempengaruhi persepsi mahasiswa secara positif dalam rangka meningkatkan keberhasilan mahasiswa.

2. Masukan bagi Jurusan Akuntansi sebagai bahan pertimbangan dalam perumusan kurikulum akuntansi pada masa datang, maupun sebagai pertimbangan dalam perumusan kebijakan terhadap mahasiswa yang berkaitan dengan mata kuliah Sistem Informasi.

\section{Tinjauan pustaka}

\subsection{Defenisi dan jenis sistem Informasi}

Meskipun terdapat defenisi Sistem Informasi yang dirangkai secara berbeda namun pada hakekatnya mempunyai maksud yang sama. Secara umum Turban, McLean dan Wetherbe (1999) menyatakan bahwa sebuah sistem informasi itu 
mengumpulkan, memproses, menyimpan, menganalisis dan menyebarkan informasi untuk tujuantujuan tertentu. Disebutkan pula bahwa sistem informasi memproses input yang berupa data dan instruksi dan menhasilkan output yang bisa berupa laporan-laporan, kalkulasi dan lain-lain. Selanjutnya Laudon dan Laudon (2000) melengkapi definisi tersebut dengan menyatakan bahwa Sistem Informasi secara tekhnis adalah sekumpulan komponen yang saling berhubungan yang mengumpulkan, memproses, menyimpan dan mendistribusikan informasi untuk mendukung pengambilan keputusan dan mendukung fungsi pengendalian dalan sebuah organisasi. Ditambahkan oleh Laudon dan laudon (2000) bahwa dalam rangka mendukung pengambilan keputusan, koordinasi dan pengendalian, sistem informasi bisa membantu manajer-manajer dan pekerja untuk menganalisis masalah yang dihadapi di perusahaan, memvisualisasikan hal-hal yang kompleks dan memunculkan inovasi dalam membuat produk baru.

Dari semua defenisi di atas terlihat pentingnya sistem informasi dalam pengambilan keputusan, pengendalian maupun tujuan-tujuan penting lainnya dalam organisasi. Selain itu juga sistem informasi bisa membantu para pekerja dalam bidang apapun untuk menganalisis masalah dalam rangka pemecahan masalah, memvisualisasikan hal-hal kompleks serta mendorong munculnya ide dan inovasi yang bisa menjadi keunggulan kompetitif bagi perusahaan.

Jenis-jenis sistem informasi itu sendiri lebih lanjut dinyatakan oleh Laudon dan Laudon sebagai berikut:

a. Transaction Processing System, melayani semua kebutuhan organisasi pada tahap operasional.

b. Knowledge Work System and Office Automation System, melayani kebutuhan perusahaan pada level pengetahuan.

c. Management Information System, melayani level manajer pada organisasi. Menyediakan informasi yang berguna bagi manajer dalam pengambilan keputusan. d. Decision Support System, juga melayani para manajer. Sistem ini membantu manager membuat keputusan semi struktur, unik dan berubah secara cepat.

e. Executive Support System, membantu petinggi perusahaan untuk membuat keputusan pada level strategis yang akan mempengaruhi perusahaan secara jangka pendek maupun jangka panjang.

Semua Sistem Informasi di atas melayani kegiatan perusahaan mulai dari tahap operasional sampai tahap eksekutif. Sehingga bisa disimpulkan bahwa semua aktivitas yang terdapat di dalam perusahaan pasti merupakan bagian dari Sistem Informasi. Untuk mengakomodasi kelancaran pelaksanaan aktivitas di perusahaan baik yang bersifat operasional maupun strategis, semua pihak yang terlibat diharapkan faham, mampu dan memiliki pengetahuan yang cukup untuk melaksanakan tugasnya terkait Sistem Informasi.

\subsection{Relevansi sistem informasi dan bidang ilmu Akuntansi}

Akuntan sebagai salah satu profesi yang penting diperusahaan mempunyai peran yang luas dan tidak hanya terbatas pada pencatatan dan pelaporan keuangan. Terlebih lagi saat ini fungsi pencatatan dan pelaporan keuangan (Akuntansi) sudah tidak lagi dilakukan secara manual. Hampir semua kejadian dan aktivitas yang timbul di perusahaan sudah diinput dan di proses oleh Sistem Pemrosesan Transaksi (Transaction Processing System) yang terkomputerisasi. Sehingga input data keuangan yang akan diolah oleh akuntan sudah berbentuk data elektronik yang kemudian akan diproses dan salah satu hasilnya adalah laporan keuangan. Sehingga jelas bahwa semua pekerjaan Akuntan sudah berkaitan erat dengan sistem informasi yang ada di perusahaan. Oleh karena itu seyogyanya akuntan tidak hanya bisa dibekali dengan ilmu akuntansi akan tetapi harus membekali diri dengan ilmu sistem informasi yang sangat relevan dengan Akuntansi. 
Menurut Wilkinson et al (2000) pilihan karir dan peran yang mungkin akan ditempati oleh para akuntan di dunia kerja adalah sebagai berikut:

1. Akuntan Keuangan (Financial Accountans), adalah bagian dari akuntansi yang menghasilkan informasi keuangan berbasis historis. Sistem Informasi Akuntansi keuangan bertujuan menyiapkan laporan keuangan yang akurat dan sesuai dengan standar akuntansi yang berlaku umum berdasarkan informasi keuangan historis tersebut. Dalam rangka mencapai tujuan ini akuntan sebagai user yang menggunakan sistem informasi akuntansi harus mengerti dan memahami cara mengoperasikan sistem yang ada di perusahaan dengan baik.

2. Manager Akuntansi (Accounting Managers)

Selain bertugas sebagai staf penyusun laporan keuangan, Akuntan dapat berperan sebagai manager baik itu di departemen Akuntansi maupun Departemen lainnya. Sebagai kepala departemen Akuntansi Akuntan harus bisa menggunakan SIA dalam rangka mengontrol aktivitas-aktivitas Akuntansi, mengevaluasi kinerja dari para staff Akuntansi dan merencanakan arah dari fungsi departemen Akuntansi di dalam perusahaan untuk jangka panjang

3. Spesialis Pajak (Tax Specialist)

4. Akuntan Manajemen (Managerial Accountants)

Kepiawaian dan pemahaman Akuntan terhadap alur data Akuntansi bisa digunakan untuk menghasilkan keputusan manajerial yang baik. Untuk itu akuntan harus mengetahui, memahami dan mampu menggunakan sistem informasi lain yang terdapat di dalam kelompok Sistem Informasi Manajemen yang berguna dalam pengambilan keputusan.

5. Pengembang Sistem (System Developer). Di dalam tim pengembang system dalam perusahaan, akuntansi bisa menempati berbagai peran. Seperti yang sudah dinyatakan oleh Hall dan Singleton (2005) bahwa auditor dalam sebuah proyek pengembangan sistem sebagai :user yang berperan aktif dalam pengembangan sistem, analyst dan auditor

6. Auditor; Auditor bertugas untuk mengevaluasi informasi sebagai produk dari sebuah sistem, baik itu informasi yang bersifat financial maupun non financial. Sejalan dengan diaplikasikannya tekhnologi dan sistem informasi di semua perusahaan, maka auditor pun harus mampu untuk mengevaluasi semua informasi yang berbentuk data elektronik dan menggunakan sistem dalam pengolahannya (Hall dan Singleton, 2005).

Meskipun hampir semua jenis Sistem Informasi relevan dengan ilmu Akuntansi, tetapi jurusan Akuntansi Universitas Andalas mengelompokkan mata kuliah Sistem Informasinya sebagai berikut:

a.Sistem Informasi Akuntansi, Menjabarkan alur informasi keuangan secara elektronik, mereview semua siklus pelaporan keuangan dalam perusahaan secara lebih detail dan membahas resiko serta ancaman yang ada di setiap siklus dan bagaimana mengendalikannya. Pada mata kuliah ini dijelaskan juga perbedaan antara semua alur dan siklus pada perusahaan konvensional dan perusahaan yang aktivitasnya sudah berbasis tekhnologi.

b.Sistem Informasi Manajemen, mengajarkan pengetahuan menyeluruh tentang Sistem Informasi seperti Virtual Organization, Decision Support System, E-commerce, ethical implications of Information Technology, System Security, dan lain-lain. (McLeod, 2007). Mata kuliah ini mempersiapkan mahasiswa Akuntansi untuk bisa menjadi manajer yang memiliki pengetahuan menyeluruh tentang Sistem Informasi yang sudah menggunakan tekhnologi terkini.

c. Analisa Perancangan Sistem, memberikan ilmu kepada para calon Akuntan yang mungkin nanti akan terlibat dalam pengembangan sistem. Seperti yang sudah disebutkan sebelumnya bahwa Akuntan bisa berperan dalam pengembangan sistem sebagai user, Analis dan Auditor. Pada mata kuliah ini mahasiswa dibekali ilmu yang mungkin 
mereka gunakan pada setiap peran tersebut terutama sebagai Analis.

d. Audit Sistem Informasi, Audit adalah salah satu profesi yang tersedia untuk para Akuntan dimasa depan. Sesuai dengan revolusi tekhnologi yang banyak merubah cara pengumpulan, pemrosesan data dan pelaporan, maka bentuk data dan informasi yang akan diaudit sudah berubah juga menjadi data elektronik. Untuk itu Akuntan diajarkan ilmu bagaimana melakukan audit melalui menggunakan Komputer (Hall dan Singleton, 2005)

Dengan mempelajari semua mata kuliah di atas diharapkan mahasiswa jurusan Akuntansi Universitas Andalas memiliki semua ilmu yang penting dan relevan dengan bidang ilmu Akuntansinya, dan bisa mempertajam daya saingnya dengan ilmu yang sesuai dengan fenomena tekhnologi terkini di dunia bisnis.

\subsection{Persepsi dan faktor-faktor yang mempengaruhinya}

Secara sederhana Widayatun (2002) menjelaskan proses munculnya persepsi pada individu yang diawali dengan adanya obyek atau ransangan yang tertangkap oleh indera manusia dan dialirkan ke otak. Kemudian otak akan mengembalikan ransangan tersebut dalam bentuk respon kembali ke panca indera pengirim berupa "tanggapan" yang merupakan output dari pengolahan ransangan pada otak. Sementara Robbins dan Judge(2011) mendefinisikan Persepsi sebagai berikut:

"Perception is a process by which individual organize and interpret their sensory impressions in order to give meaning to their environment"

Defenisi di atas menyatakan bahwa dengan persepsi setiap orang secara individual mengatur dan menginterpretasikan apa yang ditangkap oleh sensor mereka. Untuk itu setiap individu bisa menghasilkan persepsi yang berbeda-beda, tergantung dengan kesan yang mereka tangkap dan bagaimana mereka menerjemahkannya. Bahkan disebutkan pula bahwa kadang apa yang ditangkap oleh sensor individu yang akhirnya menjadi persepsi bisa berbeda dengan realita. Tentu saja ini membuat persepsi menjadi penting dalam proses belajar, karena orangorang berperilaku berdasarkan persepsi mereka tentang realita, dan bukan berdasarkan realita yang sebenarnya ada.

Selain kesan yang ditangkap oleh sensor dan panca indera individu, Sementara faktor-faktor yang mempengaruhi persepsi oleh Robbins dan Judge (2011) digambarkan melalui sebagai berikut:

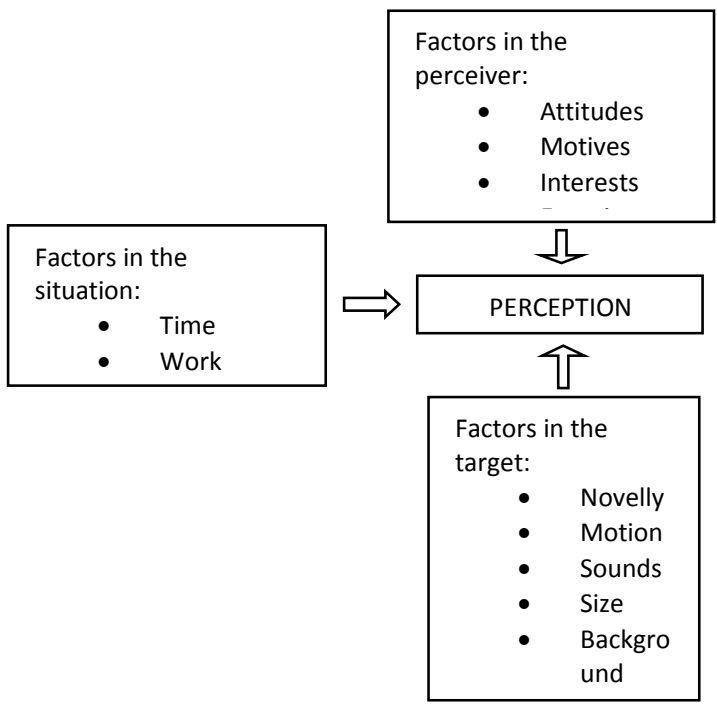

Gambar 1. Faktor yang mempengaruhi terbentuknya persepsi (Robin dan Judge, 2011)

\subsection{Persepsi dan pengaruhnya terhadap proses belajar}

Dalam penelitiannya Fatimah (2009) menemukan bahwa persepsi yang baik akan suatu bidang ilmu membantu terbentuknya motivasi yang kuat dalam diri mahasiswa tersebut. Motivasi ini membantu para mahasiswa untuk mempelajari bidang ilmu yang dimaksud dengan lebih baik yang berpengaruh pada semakin baiknya performance mereka pada mata kuliah ilmu yang bersangkutan. Selanjutnya ibadi et al (2009) juga mendapatkan hasil yang sama bahwa persepsi mahasiswa mempunyai pengaruh pada hasil belajarnya walaupun tidak terlalu signifikan, karena banyak faktor lain yang juga mempengaruhi prestasi belajar mahasiswa. 
Dari hasil penelitian terdahulu tersebut dapat kita simpulkan bahwa persepsi mempunya pengaruh positif terhadap prestasi belajar mahasiswa. Hal ini dikarenakan persepsi dan pemahaman yang baik tentang pentingnya bidang ilmu yang mereka pelajari menimbulkan motivasi, minat belajar, ketertarikan maupun keinginan untuk sukses (prasetyo, 2011) yang bisa mendorong ketekunan dan keseriusan dalam proses belajar mereka. Hal ini tentu berpengaruh positif terhadap prestasi belajar.

\section{Metode penelitian \\ 3.1 Metode pengumpulan data}

Metode pengumpulan data yang digunakan dalam penelitian ini adalah metode survey. Kuesioner ini didistribusikan pada 60 mahasiswa dari 6 kelas sistem informasi yang diikuti oleh mahasiswa akuntansi semester ganjil tahun akademik 2012/2013.

\subsection{Populasi dan Sampel}

Populasi penelitian ini adalah mahasiswa Akuntansi Universitas Andalas. Sementara sampelnya adalah mahasiswa jurusan Akuntansi Universitas Andalas yang sedang mengambil mata kuliah-mata kuliah sistem informasi.

Sampel diambil denga menggunakan metode Simple Random Sampling dari mahasiswa Akuntansi yang sudah selesai mengambil mata kuliah Sistem Informasi Akuntansi dan saat ini sedang mengambil mata kuliah sistem Informasi lanjutan lainnya.

\subsection{Variabel Penelitian dan Pengukuran Variabel}

Penelitian akan lebih di fokuskan pada upaya menggali opini terkait dengan persepsi para mahasiswa jurusan Akuntansi terhadap segala aspek pembelajaran mata kuliah sistem informasi. Tujuannya adalah untuk bisa mengidentifikasi factor-faktor yang mempengaruhi persepsi mahasiswa dan bagaimana hal itu bisa mempengaruhi performance mahasiswa tersebut pada mata kuliah sistem informasi yang mereka ambil. Diharapkan juga akan bisa mengidentifikasi hambatan-hambatan yang bisa mempengaruhi persepsi dan performance mereka dalam proses belajar.

\subsection{Instrumen Penelitian}

Instrument penelitian dikelompokan dalam 4 bagian utama. Bagian pertama menanyakan pendapat responden mengenai pengajaran mata kuliah Sistem Informasi Akuntansi yang sudah mereka ambil dilihat dari berbagai aspek yaitu fasilitas, pengajar, metode pengajaran dan lainlain. Pada bagian ini responden juga diminta memberikan informasi mengenai nilai yang mereka dapat pada mata kuliah Sistem Informasi Akuntansi. Pertanyaan pada bagian ini berupa pilihan berganda. Bagian kedua menanyakan persepsi masingmasing responden mengenai relevansi dari pengajaran matakuliah Sistem Informasi dengan bidang ilmu utama yang mereka pelajar yaitu Akuntansi. Dengan menggunakan skala likert 1-5 para responden diminta pendapat mereka mengenai berbagai pernyataan terkait dengan relevansi pengajaran sistem Informasi, dimana poin satu = sangat tidak setuju, 3= netral dan poin $5=$ sangat setuju.

Bagian tiga menanyakan persepsi para responden mengenai urgensi dan manfaat pengajaran Sistem Informasi di jurusan Akuntansi. dengan menggunakan skala likert 1-5 para responden diminta pendapat mereka mengenai berbagai pernyataan terkait dengan urgensi dan manfaat pengajaran sistem Informasi, dimana poin satu $=$ tidak penting poin, $3=$ netral dan poin $5=$ paling penting. Bagian ke-empat menanyakan persepsi para responden mengenai faktor- faktor yang menjadi kendala dalam pengajaran Akuntansi Forensik. Dengan menggunakan skala likert 1-5 para responden diminta pendapat mereka mengenai berbagai pernyataan terkait dengan faktor-faktor yang menjadi kendala dalam pengajaran Akuntansi Forensik, dimana poin satu $=$ tidak terlalu menghambat dan poin $5=$ sangat menghambat 
Di bagian akhir responden diminta memberi pendapat atau saran jika ada yang menurut mereka penting diaplikasikan pada pengajaran mata kuliah sistem informasi itu sendiri. Bagian ini optional dimana responden boleh memilih akan mengisi tempat yang disediakan atau tidak.

\subsection{Teknik Analisis Data}

Data dan informasi yang diperoleh dianalisis secara kuantitatif dan kualitatif. Standar-standar pengolahan dan analisis data mengikuti Yamin \& Kurniawan (2009). Analisis kuantitatif menggunakan descriptive statistics untuk mengetahui persepsi mahasiswa terhadap mata kuliah Sistem Informasi di Jurusan Akuntansi.

\section{Hasil dan pembahasan}

\section{A. Analisis Hasil Penelitian}

Kuesioner di sebar ke 70 orang mahasiswa Jurusan Akuntansi pada 7 kelas Sistem Informasi lanjutan dari Sistem Informasi Akuntansi yaitu : Audit Sistem Informasi, Analisa Perancangan Sistem, Sistem Informasi Manajemen yang diasuh oleh dosen yang berbeda. Tingkat pengembalian Kuesioner mencapai 100\% karena responden berupa mahasiswa jurusan Akuntansi Universitas Andalas cukup kooperatif. Hal ini dikarenakan sebelum mengisi kuesioner mereka diinformasikan bahwa penelitian ini tidak mempengaruhi nilai dan ditujukan untuk memperbaiki kualitas pengajaran mata kuliah Sistem Informasi di jurusan Akuntansi Universitas Andalas. Responden diambil secara acak dengan tidak memperhatikan perbedaan Gender dan Usia.

Di dalam penelitian, meskipun terdapat beberapa faktor dari dalam diri mahasiswa yang mempengaruhi keberhasilan mereka dalam proses belajar, akan tetapi dalam penelitian ini penulis memfokuskan pada faktor persepsi. Jajak pendapat yang (survey) dilakukan terhadap objek penelitian yang terdiri dari mahasiswa jurusan Akuntansi di Universitas Andalas lebih menitikberatkan kepada pendapat dan cara pandang mahasiswa terhadap mata kuliah sistem informasi yang mereka ambil. Lebih jauh lagi cara pandang ini akan dilihat seberapa besar pengaruhnya dalam membangun motivasi dan kemauan belajar mereka, dalam rangka meningkatkan prestasi belajar pada mata kuliah sistem yang mereka ambil.

\section{B. Gambaran Umum Responden}

Responden Mahasiswa yang berpartisipasi dalam penelitian ini semuanya telah mengambil mata kuliah Sistem Informasi Akuntansi yang merupakan mata rantai awal siklus mata kuliah sistem informasi di Jurusan Akuntansi. Berikut perolehan nilai dari perkuliahan SIA yang sudah mereka ambil sebelumnya:

Tabel 1. Nilai Mata Kuliah SIA

\begin{tabular}{|c|c|c|}
\hline Nilai SIA & $\begin{array}{c}\text { Jumlah } \\
\text { Mahasiswa } \\
\text { (Orang) }\end{array}$ & $\begin{array}{c}\text { Persentase } \\
\text { (\%) }\end{array}$ \\
\hline A & 2 & 3 \\
\hline A- & 7 & 10 \\
\hline B+ & 8 & 11 \\
\hline B & 18 & 26 \\
\hline B- & 2 & 3 \\
\hline C+ & 8 & 11 \\
\hline C & 11 & 16 \\
\hline C- & 2 & 3 \\
\hline D & 3 & 4 \\
\hline $\begin{array}{c}\text { Tidak Bersedia } \\
\text { memberitahu } \\
\text { nilai }\end{array}$ & 9 & 13 \\
\hline TOTAL & 70 & \\
\hline
\end{tabular}

Dari table di atas terlihat bahwa mahasiswa yang menjadi responden mendapatkan nilai yang bervariasi, tapi dari nilai tersebut rata-rata mendapatkan nilai yang cukup baik. Terlihat bahwa angka terbesar $26 \%$ atau sebanyak 18 orang mendapatkan nilai B. Sementara angka terendah sebanyak $3 \%$ atau 2 orang mendapatkan nilai C- dan A. Bisa disimpulkan bahwa responden ratarata mendapatkan hasil yang cukup memuaskan dari mata kuliah SIA yang mereka ambil sebelumnya. 
Tabel 2. Mata kuliah yang sudah diambil

\begin{tabular}{|l|l|c|c|}
\hline $\begin{array}{c}\text { Mata } \\
\text { Kuliah } \\
\text { yang } \\
\text { sedang } \\
\text { diambil }\end{array}$ & $\begin{array}{c}\text { Mata Kuliah } \\
\text { yang sudah } \\
\text { diambil }\end{array}$ & $\begin{array}{c}\text { Jmlh } \\
\text { Responden } \\
\text { (Org) }\end{array}$ & $\%$ \\
\hline APS & SIA & 40 & $57 \%$ \\
\hline SIM & $\begin{array}{l}\text { SIA dan } \\
\text { APS, }\end{array}$ & 10 & $14 \%$ \\
\hline $\begin{array}{l}\text { AUDIT } \\
\text { SI }\end{array}$ & $\begin{array}{l}\text { SIA, APS } \\
\text { dan SIM }\end{array}$ & 20 & $29 \%$ \\
\hline
\end{tabular}

Responden rata-rata jumlahnya tidak jauh berbeda antara yang sudah mengambil satu mata kuliah siklus saja yaitu $57 \%$ (dengan asumsi semuanya baru mengambil dan tidak ada mahasiswa yang mengulang pada mata kuliah ini) dengan mahasiswa yang sudah berpengalaman mengambil mata kuliah siklus sistem informasi lebih dari satu yaitu $43 \%$. Ini bisa diartikan bahwa pendapat yang mereka berikan berimbang antara yang belum begitu berpengalaman mengambil beberapa mata kuliah sistem informasi yang beragam dengan yang sudah berpengalaman. Pendapat mereka pun bisa dianggap bisa diandalkan karena mereka ratarata sudah punya perbandingan pengalaman mengambil mata kuliah sistem informasi dengan tingkat kesulitan, jenis materi dan dosen yang berbeda. Selain itu pengetahuan mereka tentang mata kuliah sistem informasi juga dianggap sudah cukup baik dan bisa memberikan pendapat yang mewakili apa yang sudah mereka pelajari.

Tabel 3. Manfaat mempelajari SIA dan relevansinya dengan pemahaman Akuntansi

\begin{tabular}{|c|c|c|}
\hline $\begin{array}{c}\text { Manfaat mengambil } \\
\text { SIA dan } \\
\text { relevansinya dengan } \\
\text { pemahaman } \\
\text { Akuntansi }\end{array}$ & $\begin{array}{c}\text { JmIh } \\
\text { responden } \\
\text { (org) }\end{array}$ & $\%$ \\
\hline $\begin{array}{l}\text { Menjadi Sangat } \\
\text { mudah memahami } \\
\text { ilmu akuntansi }\end{array}$ & 18 & $26 \%$ \\
\hline $\begin{array}{l}\text { Menjadi lebih mudah } \\
\text { tapi tidak signifikan }\end{array}$ & 45 & $64 \%$ \\
\hline $\begin{array}{l}\text { Tidak berpengaruh } \\
\text { apa-apa }\end{array}$ & 6 & $9 \%$ \\
\hline $\begin{array}{l}\text { Tidak ada manfaat } \\
\text { sama sekali }\end{array}$ & 1 & $1 \%$ \\
\hline TOTAL & $\mathbf{7 0}$ & $\mathbf{1 0 0} \%$ \\
\hline
\end{tabular}

Tabel 3 menggambarkan pendapat mahasiswa tentang manfaat yang mereka dapat dari mempelajari SIA dalam bentuk penambahan wawasan keilmuan dan bagaimana peningkatan wawasan keilmuan tersebut berpengaruh terhadap pemahaman mereka terhadap bidang ilmu yang mereka pelajari yaitu akuntansi. Dari angka yang terdapat pada table terlihat bahwa lebih dari setengah jumlah responden yaitu sebesar $64 \%$ (45 responden) menyatakan mereka merasakan manfaat dari mempelajari matakuliah SIA, walaupun itu tidak terasa sangat signifikan. Hal ini dapat dimaklumi karena SIA baru mata kuliah pertama pada siklus sistem informasi yang dipelajari oleh mahasiswa jurusan akuntansi. Lebih jauh lagi angka terbesar kedua sebanyak 26\% dari jumlah responden (sebanyak 18 orang) bahkan menyatakan bahwa sejak mempelajari SIA menjadi sangat mudah bagi mahasiswa untuk memahami bidang ilmu akuntansi secara signifikan. Dengan demikian dapat disimpulkan bahwa dengan mempelajari mata kuliah sistem informasi sebagai ilmu pendukung, mahasiswa merasakan manfaat yang sangat besar dalam mempelajari bidang ilmu spesifik mereka yaitu akuntansi.

Tabel 4. Faktor yang mempengaruhi keberhasilan SIA

\begin{tabular}{|l|c|c|}
\hline $\begin{array}{l}\text { Faktor yang } \\
\text { mempengaruhi } \\
\text { keberhasilan SIA }\end{array}$ & $\begin{array}{c}\text { Jumlah } \\
\text { responden } \\
\text { (orang) }\end{array}$ & $\%$ \\
\hline $\begin{array}{l}\text { Motivasi diri } \\
\text { Mahasiswa }\end{array}$ & 24 & $34 \%$ \\
\hline Metode ajar & 16 & $23 \%$ \\
\hline $\begin{array}{l}\text { Kelengkapan } \\
\text { fasilitas }\end{array}$ & 2 & $3 \%$ \\
\hline $\begin{array}{l}\text { Wawasan dan cara } \\
\text { transfer ilmu dari } \\
\text { dosen }\end{array}$ & 28 & $40 \%$ \\
\hline TOTAL & $\mathbf{7 0}$ & $\mathbf{1 0 0} \%$ \\
\hline
\end{tabular}


Setelah diminta pendapat responden tentang pengaruh dan relevansi mempelajari SIA dengan kemudahan mereka memahami akuntansi, responden juga diminta pendapat mengenai factor apa saja yang mempengaruhi tingkat keberhasilan mereka mempelajari SIA baik dari segi nilai maupun pemahaman. Pada table 4 terlihat bahwa ada tiga factor yang menurut mereka sangat berpengaruh dengan nilai rata-rata yang tidak jauh berbeda yaitu : Wawasan dan cara transfer ilmu dari dosen saat mengajar (40\%), motivasi diri mahasiswa (34\%), dan metode pengajaran yang digunakan (23\%). Hanya kelengkapan fasilitas yang oleh hampir semua responden dianggap tidak terlalu berpengaruh pada keberhasilan mereka dalam mempelajari SIA dengan angka persentase hanya $3 \%$.

Tabel 5. Pengaruh SIA Terhadap Pembelajaran Mata Kuliah SI

$$
\text { berikutnya }
$$

\begin{tabular}{|l|c|c|}
\hline $\begin{array}{c}\text { Pengaruh SIA } \\
\text { Terhadap } \\
\text { Pembelajaran Mata } \\
\text { Kuliah SI berikutnya }\end{array}$ & $\begin{array}{c}\text { Jumlah } \\
\text { responden } \\
\text { (orang) }\end{array}$ & $\%$ \\
\hline Menjadi lebih mudah & 15 & $21 \%$ \\
\hline $\begin{array}{l}\text { Lebih mudah tapi tidak } \\
\text { signifikan }\end{array}$ & 26 & $37 \%$ \\
\hline $\begin{array}{l}\text { Tidak ada manfaat } \\
\text { mempelajari SIA } \\
\text { sebelumnya }\end{array}$ & 11 & $16 \%$ \\
\hline $\begin{array}{l}\text { Tetap kesulitan dan } \\
\text { harus belajar keras }\end{array}$ & 18 & $26 \%$ \\
\hline TOTAL & $\mathbf{7 0}$ & $\mathbf{1 0 0} \%$ \\
\hline
\end{tabular}

Selain melihat pengaruh perubahan pemahaman responden setelah mempelajari SIA terhadap bidang ilmu akuntansi, mereka juga ditanyakan pengaruhnya dalam mepelajari mata kuliah berikutnya pada siklus sistem informasi. Dari table 5 terlihat bahwa hampir sebagian merasakan pengaruhnya dimana $21 \%$ responden menyatakan bahwa lebih mudah buat mereka dalam mempelajari mata kuliah. Ditambah jumlah responden yang lebih besar lagi sebesar $37 \%$ atau 26 responden mengakui bahwa mereka merasakan kemudahan dalam mempelajari matakuliah sistem informasi walaupun belum begitu signifikan. Walaupun sebagian besar mengakui merasakan kemudahan belajar sistem informasi setelah mempelajari SIA, akan tetapi $26 \%$ responden merasa bahwa mereka tetap mengalami kesulitan dan harus bekerja keras jika ingin mendapatkan hasil yang memuaskan. Sementara itu hanya $16 \%$ atau 11 orang responden yang menyatakan tidak merasakan pengaruh atau manfaat sama sekali terhadap proses belajar mereka pada mata kuliah sistem informasi berikutnya.

Tabel 6. Perubahan Motivasi dan Cara Pandang pada Mata Kuliah SI Saat Ini

\begin{tabular}{|l|c|c|}
\hline $\begin{array}{c}\text { Perubahan Motivasi dan } \\
\text { Cara Pandang pada Mata } \\
\text { Kuliah SI Saat Ini }\end{array}$ & $\begin{array}{c}\text { Jumlah } \\
\text { responden } \\
\text { (orang) }\end{array}$ & $\%$ \\
\hline $\begin{array}{l}\text { Lebih termotivasi dan } \\
\text { menikmati }\end{array}$ & 21 & $30 \%$ \\
\hline $\begin{array}{l}\text { Lebih termotivasi karena } \\
\text { tidak mau mengulang }\end{array}$ & 32 & $46 \%$ \\
\hline $\begin{array}{l}\text { Tidak termotivasi karena } \\
\text { lebih tidak menarik dari SIA }\end{array}$ & 4 & $6 \%$ \\
\hline Sama saja dengan SIA & 13 & $19 \%$ \\
\hline TOTAL & $\mathbf{7 0}$ & $\mathbf{1 0 0}$ \\
\hline
\end{tabular}

Pada table 6, peneliti meminta responden membandingkan antara motivasi dan cara pandang mereka saat mempelajari SIA dengan kondisi wawasan dan persepsi mereka saat mengambil mata kuliah lanjutan yang sedang mereka pelajari. Dari seluruh responden $76 \%$ menyatakan lebih termotivasi saat mengambil mata kuliah lanjutan ini, sayangnya sebagian besar mereka yaitu $46 \%$ termotivasi karena tidak ingin mengulang. Lebih lanjut, hanya $30 \%$ responden yang mengalami peningkatan motivasi dan menikmati proses pembelajaran saat ini. Sisanya sebesar $25 \%$ menyatakan tidak termotivasi karena mata kuliah saat ini tidak lebih menarik dan merasa sama saja dengan sewaktu mereka mengambil SIA. 


\section{Uji Validitas dan Reliabilitas}

Sesuai dengan yang diungkapkan oleh Yamin dan Kurniawan (2009) mengenai cara pengujian validitas dan reliabilitas, setelah melakukan proses pengolahan melalui SPSS (Statistical Package for Social Science) versi 16.0 didapat hasil bahwa semua pertanyaan yang terdapat pada kuesioner memiliki nilai corrected itemtotal correlation yang lebih besar dari $r$ table (0.235). Ini berarti bahwa semua item pertanyaan yang ada di dalam kuesioner dinyatakan valid. Dengan demikian bisa disimpulkan bahwa semua item pertanyaan tersebut bisa digunakan pada pengolahan selanjutnya.

Selain melakukan uji validitas, peneliti juga melakukan pengujian reliabilitas dengan melihat angka Cronbach's alpha pada table-tabel berikut:

\begin{tabular}{|c|c|c|}
\hline & $\begin{array}{l}\text { Statistics- pert } \\
\text { kelompok B }\end{array}$ & \\
\hline $\begin{array}{c}\text { Cronbach's } \\
\text { Alpha }\end{array}$ & $\begin{array}{c}\text { Cronbach's Alpha } \\
\text { Based on } \\
\text { Standardized } \\
\text { Items }\end{array}$ & $\begin{array}{c}\mathrm{N} \text { of } \\
\text { Items }\end{array}$ \\
\hline .630 & .632 & \\
\hline
\end{tabular}

Reliability Statistics- pertanyaan kelompok C

\begin{tabular}{|r|r|r|}
\hline $\begin{array}{c}\text { Cronbach's } \\
\text { Alpha }\end{array}$ & $\begin{array}{c}\text { Cronbach's Alpha } \\
\text { Based on } \\
\text { Standardized } \\
\text { Items }\end{array}$ & $\begin{array}{c}\mathrm{N} \text { of } \\
\text { Items }\end{array}$ \\
\hline .829 & .832 & 5 \\
\hline
\end{tabular}

Reliability Statistics - pertanyaan kelompok D

\begin{tabular}{|c|c|c|}
\hline $\begin{array}{c}\text { Cronbach's } \\
\text { Alpha }\end{array}$ & $\begin{array}{c}\text { Cronbach's Alpha } \\
\text { Based on } \\
\text { Standardized } \\
\text { Items }\end{array}$ & $\begin{array}{c}\mathrm{N} \text { of } \\
\text { Items }\end{array}$ \\
\hline .686 & .689 & 5 \\
\hline
\end{tabular}

Item-Total Statistics

\begin{tabular}{|c|c|c|c|c|c|}
\hline & $\begin{array}{l}\text { Scale } \\
\text { Mean if } \\
\text { Item } \\
\text { Deleted }\end{array}$ & \begin{tabular}{|c|} 
Scale \\
Varianc \\
e if Item \\
Deleted
\end{tabular} & $\begin{array}{l}\text { Corrected } \\
\text { Item-Total } \\
\text { Correlation }\end{array}$ & $\begin{array}{c}\text { Squared } \\
\text { Multiple } \\
\text { Correlation }\end{array}$ & $\begin{array}{l}\text { Cronbach's } \\
\text { Alpha if Item } \\
\text { Deleted }\end{array}$ \\
\hline B1 & 13.67 & 8.402 & .597 & .437 & .464 \\
\hline B2 & 13.87 & 8.645 & .618 & .511 & .463 \\
\hline B3 & 15.00 & 14.647 & -.256 & .098 & .838 \\
\hline B4 & 13.46 & 8.782 & .562 & .526 & .488 \\
\hline B5 & 13.74 & 7.490 & .630 & .531 & .427 \\
\hline \multicolumn{6}{|c|}{ Item-Total Statistics } \\
\hline & $\begin{array}{l}\text { Scale } \\
\text { Mean if } \\
\text { Item } \\
\text { Deleted }\end{array}$ & $\begin{array}{c}\text { Scale } \\
\text { Variance } \\
\text { if Item } \\
\text { Deleted }\end{array}$ & $\begin{array}{l}\text { Correctec } \\
\text { Item-Tota } \\
\text { Correlatio }\end{array}$ & $\begin{array}{c}\text { Squared } \\
\text { Multiple } \\
\text { Correlation }\end{array}$ & $\begin{array}{l}\text { Cronbach's } \\
\text { Alpha if } \\
\text { Item } \\
\text { Deleted }\end{array}$ \\
\hline C1 & 15.23 & 9.454 & & .525 & .776 \\
\hline $\mathrm{C} 2$ & 15.77 & 10.237 & & .321 & .833 \\
\hline C3 & 15.80 & 10.220 & & .520 & .780 \\
\hline C4 & 15.46 & 9.208 & & .579 & .758 \\
\hline C5 & 15.40 & 11.026 & & .420 & .821 \\
\hline
\end{tabular}

\begin{tabular}{|c|c|c|c|c|c|c|}
\hline & $\begin{array}{l}\text { Scale } \\
\text { Mean if } \\
\text { Item } \\
\text { Deleted }\end{array}$ & $\begin{array}{c}\text { Scale } \\
\text { Varianc } \\
\text { e if Item } \\
\text { Deleted }\end{array}$ & $\begin{array}{l}\text { Corrected } \\
\text { Item-Total } \\
\text { Correlation }\end{array}$ & $\begin{array}{c}\text { Squared } \\
\text { Multiple } \\
\text { Correlation }\end{array}$ & \multicolumn{2}{|c|}{$\begin{array}{l}\text { Cronbach's } \\
\text { Alpha if Item } \\
\text { Deleted }\end{array}$} \\
\hline D1 & 15.04 & 13.013 & .561 & & .363 & \\
\hline D2 & 15.38 & 12.444 & .562 & & .382 & \\
\hline D3 & 15.13 & 14.586 & .321 & & .139 & .68 \\
\hline D4 & 15.06 & 13.702 & .420 & & .218 & \\
\hline D5 & 15.28 & 14.055 & .359 & & .138 & 67 \\
\hline
\end{tabular}

Untuk semua pertanyaan terlihat bahwa angka cronbach's alpha lebih dari 0.5 (atau mendekati angka 1) sehingga bisa disimpulkan bahwa semua pertanyaan pada kelompok ini Iulus uji reliabilitas. Bisa disimpulkan dari table bahwa pertanyaan pada masing-masing kelompok reliable sebesar 63\%, $82.9 \%$ dan $68.6 \%$. Sehingga bisa diambil kesimpulan bahwa semua item pertanyaan didalam kuesioner selain valid juga reliable.

\section{Analisis Deskriptif}

Seperti halnya analisis statistic yang dilakukan oleh surya dan setiyaningrum (2009) yang memiliki karakteristik pengolahan data yang mirip dengan penelitian persepsi yang penulis lakukan, analisis akan 
dilakukan dengan menggunakan table distribusi frekuensi. Pada table tersebut akan dihitung nilai rata-rrata (Mean). Distribusi frekuensi ini berfungsi untuk mengkalkulasi besarnya frekuensi data dari masingmasing kelompok data. Rumus yang akan digunakan untuk menghitung Mean sesuai dengan yang dikemukakan oleh Supranto (1994) dalam surya dan setiyaningrum (2009) yaitu:

\section{Dimana:}

$$
\text { Mean }=\frac{\sum f i x i}{n}
$$

fi merupakan jumlah frekuensi xi merupakan nilai/ bobot variable n merupakan jumlah responden. Pengelompokan setiap indikator dihitung berdasarkan pemberian bobot nilai yang diperoleh dari hasil kuesioner dengan cara perhitungan rentang skala yang diperoleh sebagai berikut:

Nilai tertinggi $=$ total responden $\mathrm{x}$ bobot tertinggi $=70 \times 5=350$ Nilai terendah $=$ total responden $\mathrm{x}$ bobot terendah $=70 \times 1=70$ Rentang skala $=$ nilai tertinggi - nilai terendah $=(350-70) / 5=56$

1. Persepsi tentang relevansi pengajaran sistem informasi dengan bidang ilmu akuntansi

Descriptive Statistics

\begin{tabular}{|l|r|r|r|r|r|c|}
\hline & & & & & & $\begin{array}{c}\text { Std. } \\
\text { Deviatio } \\
\mathrm{n}\end{array}$ \\
\hline D1 & 70 & 4 & 1 & 5 & 3.89 & 1.291 \\
D2 & 70 & 4 & 1 & 5 & 3.57 & 1.357 \\
D3 & 70 & 4 & 1 & 5 & 3.83 & 1.329 \\
D4 & 69 & 4 & 1 & 5 & 3.91 & 1.337 \\
D5 & 70 & 4 & 1 & 5 & 3.67 & 1.380 \\
Valid N & & & & & & \\
(listwis & 69 & & & & & \\
e) & & & & & & \\
\hline
\end{tabular}

Interpretasi hasil perhitungan rata-rata:

$3,28-5.00=$ Sangat Setuju (SS)

$2,71-3,27=$ Setuju (S)

$2,14-2,70=$ Cukup Setuju (CS)

$1,57-2,13=$ Kurang Setuju (KS)

$1,00-1,56=$ Tidak Setuju (TS)

Dari semua pertanyaan pada kelompok B yang berkaitan dengan seberapa besar relevansi pengajaran sistem informasi dengan bidang ilmu akuntansi, hampir semua pertanyaan memiliki Mean pada interval teratas yaitu diatas 3,28. Ini menjelaskan bahwa hampir semua responden sangat setuju dan memiliki persepsi positif bahwa pengajaran sistem informasi sangat relevan dengan bidang ilmu akuntansi. Mereka memahami pentingnya mata kuliah ini dalam mendukung wawasan keilmuan akuntansi yang mereka miliki. Disamping itu mereka juga meyakini bahwa ilmu SI dan tekhnologi sangat mempengaruhi keberhasilan Akuntan dalam berkarir dalam dunia kerja. Bahkan mereka juga memiliki persepsi bahwa tanpa ilmu dan pemahaman tentang sistem informasi yang baik, maka Akuntan tidak akan bisa melaksanakan tugas dan pekerjaannya dengan baik.

Hanya ada satu butir pertanyaan yang berada diinterval bawah yaitu 2.43. Hal ini bisa dipahami karena butir pertanyaan tersebut menyatakan tidak ada perbedaan pemahaman responden terhadap bidang keilmuannya antara sebelum dan sesudah mengambil mata kuliah sistem informasi. Karena Hanya segelintir responden yang memiliki persepsi positif tentang ini maka angka pada butir pertanyaan ini menjadi lebih rendah dibanding ke empat butir pertanyaan lainnya.

2. Persepsi tentang manfaat dan urgensi pengajaran sistem informasi

Interpretasi hasil perhitungan rata-rata: $3,28-5.00=$ Sangat Penting (SP) $2,71-3,27=$ Penting $(P)$ $2,14-2,70=$ Cukup Penting (CP) $1,57-2,13=$ Kurang Penting (KP) $1,00-1,56=$ Tidak Penting (TS)

Sesuai dengan penghitungan Mean yang berasal dari table di atas terlihat bahwa semua butir pertanyaan memiiliki Mean di interval teratas. Ini berarti bahwa semua butir pertanyaan membuktikan persepsi responden tentang bermanfaat dan urgennya pengajaran sistem informasi bagi 
mahasiswa di jurusan Akuntansi. Dimana mereka meyakini bahwa semua pekerjaan dan tugas Akuntan tidak bisa lepas dari penggunaan tekhnologi informasi. Para responden juga menyatakan kalo sangat urgen bagi mereka untuk mengambil mata kuliah pendukung lainnya terutama sistem informasi. Dimana dengan mempelajari SI responden mendapatkan manfaat yang besar dalam banyak hal diantaranya menyelesaikan masalah dalam bidang keilmuan akuntansi, mempengaruhi perkembangan karir mereka nantinya kalo sudah menjadi Akuntan dan dapat mengaplikasikan pekerjaan Akuntan tanpa harus terhambat dengan tekhnologi dan aplikasi yang terlibat dalam pekerjaan tersebut.

3. Persepsi tentang factor-faktor yang menghambat pengajaran sistem informasi di Jurusan Akuntansi

Interpretasi hasil perhitungan rata-rata: $3,28-5.00=$ Sangat Menghambat (SM)

$2,71-3,27=$ Menghambat $(\mathrm{M})$

2,14 - 2,70 = Cukup Menghambat (CM)

$1,57-2,13=$ Kurang Menghambat (KM)

$1,00-1,56=$ Tidak Menghambat $(\mathrm{TM})$

Descriptive Statistics
\begin{tabular}{|l|r|r|r|r|r|r|}
\hline & N & Range & Min & Max & Mean & $\begin{array}{c}\text { Std. } \\
\text { Deviation }\end{array}$ \\
\hline B1 & 70 & 4 & 1 & 5 & 3.77 & 1.144 \\
B2 & 70 & 4 & 1 & 5 & 3.57 & 1.071 \\
B3 & 69 & 4 & 1 & 5 & 2.43 & 1.169 \\
B4 & 70 & 4 & 1 & 5 & 3.99 & 1.110 \\
B5 & 70 & 4 & 1 & 5 & 3.70 & 1.301 \\
Valid & & & & & & \\
N & 69 & & & & & \\
(listw & 69 & & & & & \\
ise) & & & & & & \\
\hline
\end{tabular}

Semua faktor yang diuraikan di tiap item pertanyaan pada kelompok ini memiliki angka rata-rata (Mean) yang tinggi (pada interval teratas). Berarti semua item yang dikemukakan itu dianggap sangat menghambat pengajaran sistem informasi di jurusan akuntansi. Faktor-faktor yang dianggap sebagai penghambat tersebut antara lain:

- Minat dan motivasi yang rendah untuk belajar sistem informasi.

- Persepsi negative mahasiswa tentang relevansi sistem informasi dengan bidang ilmu akuntansi.

- Cara penyampaian dan transfer ilmu dosen (masih konvensional dan teacher center learning).

- Kurangnya fasilitas pendukung metode interaktif yang menarik dan melibatkan tekhnologi informasi.

- Wawasan dosen yang mereka anggap kurang

- Dan lain-lain.

\section{Kesimpulan}

Berdasarkan survey yang dilakukan terhadap mahasiswa jurusan Akuntansi mengenai persepsi mereka terhadap mata kuliah sistem informasi dapat disimpulkan beberapa hal sebagai berikut:

1. Semua responden baik akademisi maupun auditor memiliki persepsi positif tentang pentingnya mempelajari sistem informasi dan relevansinya dengan peningkatan wawasan bidang keilmuan akuntansi. Mereka percaya bahwa sistem informasi sangat membantu memahami bidang ilmu akuntansi dan menyelesaikan masalahmasalah tertentu. Selain itu diyakini pula bahwa pengetahuan yang baik tentang sistem informasi dan tekhnologi informasi memberikan peluang kemudahan dan kelancaran dalam menjalani karir nantinya sebagai akuntan.

2. Responden terbukti memiliki persepsi positif terhadap pembelajaran sistem informasi. Hal ini dirasakan memberi manfaat dalam mendapatkan penilaian yang baik. Ditambah lagi pemahaman yang baik pada sistem informasi sebagai ilmu pendukung membantu 
memahami bidang ilmu akuntansi dengan lebih baik pula.

3. Ditemukan bahwa terdapat banyak factor yang mempengaruhi mahasiswa akuntansi dalam mempelajari sistem informasi. Dan terlihat bahwa factor penting berada pada factor manusianya yaitu mahasiswa itu sendiri dan dosen pengajar. Motivasi dan cara pandang mahasiswa serta cara pengajaran dan wawasan dosen pengajar diyakini oleh para responden sebagai factor utama yang berpengaruh terhadap keberhasilan mereka dalam mempelajari mata kuliah sistem informasi ini.

4. Sementara factor-faktor yang dianggap menghambat proses pembelajaran sistem informasi di jurusan akuntansi adalah sebagai berikut:

- Minat dan motivasi yang rendah untuk belajar sistem informasi.

- Persepsi negative mahasiswa tentang relevansi sistem informasi dengan bidang ilmu akuntansi.

- Cara penyampaian dan transfer ilmu dosen (masih konvensional dan teacher center learning).

- Kurangnya fasilitas pendukung metode interaktif yang menarik dan melibatkan tekhnologi informasi.

- Wawasan dosen yang mereka anggap kurang

5. Besar harapan dari responden yang terlihat dari banyaknya yang memberikan saran agar perkuliahan sistem informasi menjadi lebih aktif dan lebih banyak melibatkan tekhnologi informasi dalam perkuliahan. Mereka merasa bahwa metode belajar yang melibatkan mahasiswa secara lansung dalam mengaplikasikan tekhnologi informasi sangat membantu membangun ketertarikan dan motivasi yang berpengaruh terhadap keberhasilan pembelajaran mata kuliah sistem informasi tersebut.

\section{Daftar pustaka}

Adriansyah. 2011. Persepsi Mahasiswa Akuntansi dan Praktisi Akuntansi Syariah Terhadap Praktisi Akuntansi Syariah di Indonesia. Makasar. Skripsi Sarjana Universitas Hasanuddin.

http://adriansyahnantu.wordpr ess.com/2012/01/27/persepsimahasiswa-akuntansi-danpraktisi-terhadap-akuntansyariah/ (Dlakses 26 September 2012)

Fatimah, MS. 2009. Hubungan Persepsi Terhadap Profesi Bidan dengan Motivasi Belajar Mahasiswa Pendidikan DIII Kebidanan. Surakarta: Karya Tulis IImiah Sarjana Sains terapan Universitas Sebelas Maret.

http://asepdadasunandar.word press.com/kti-hubunganpersepsi-terhadap-motivasibelajar/ (Diakses 30 September 2012)

Hall J.A and Singleton T. 2005. Information Technology Auditing and Assurance. Second Edition. USA. South Western-Thomson Learning, Inc.

Ibadi M. et al, 2009. Pengaruh Perspsi Mahasiswa Tentang Variasi Mengajar Dosen Terhadap Hasil Belajar Dalam Mata Kuliah Tekhnik Permesinan. Semarang: Jurnal PTM Volume 9 No. 1 edisi Juni 2009.

Laudon K.C and Laudon J.P. 2000. Management Information System. Sixth Edition.USA. Prentice Hall, Inc.

McLeod Jr. R and Schell.G. 2007. Management Information System. Tenth Edition. USA. Pearson Prentice Hall.

Prasetyo L.C. 2011. Pengaruh Minat Belajar dan Persepsi Kerja Terhadap Prestasi Belajar Siswa. Semarang: Skripsi Sarjana IKIP Veteran.

Robbins S.P and Judge T.A. 2011. Organizational Behaviour. USA. Pearson International Edition. Pearson, Inc. 
Surya a. \& setiyaningrum a. 2009. Analisis persepsi konsumen pada aplikasi bauran pemasaran serta hubungannya terhadap loyalitas konsumen (studi kasus pada hypermart cabang kelapa gading). Jakarta. Journal of Business Strategy and Execution 2 (2009) 13 39.

Turban, McLean, Wetherbe. 1999. Information Technology for Management: Making Connections for Strategic Advantage. USA. John Wiley \& Sons, Inc.

Widayatun T.R. 2002. IImu Perilaku. Jakarta: CV Sagung Seto.

Wilkinson J.W et al. 2000. Accounting Information System : Essential Concepts and Applications. Fourth Edition. USA. John Wiley \& Sons, Inc.

Yonnedi E. Et al. 2010. Pengajaran akuntansi forensik di indonesia: Persepsi Akademisi dan Auditor di Sumatera Barat. Padang. Penelitian Jurusan Akuntansi Universitas Andalas.

Yamin S. \& Kurniawan H. 2009. SPSS complete : Tekhnik Analisis Statistik Terlengkap dengan Software SPSS. Seri 1. Jakarta. Penerbit Salemba Infotek. 